\title{
Treatment of HBeAg-Negative Chronic Hepatitis B Patients with Nucleos(t)ide Analogues in Burkina Faso
}

\section{Kounpiélimé Sosthène Somda ${ }^{1}$, Abdel Karim Sermé1, Aboubacar Coulibaly ${ }^{1}$, Steve Léonce Zoungrana ${ }^{2}$, Inès Compaoré1, Serges Kouamou ${ }^{1}$, Damien Ouattara², Roger Sombié1, Alain Bougouma1}

\author{
${ }^{1}$ Hepato-Gastroenterology Unit, Teaching Hospital Yalgado Ouédraogo, Ouagadougou, Burkina Faso \\ ${ }^{2}$ Gastroenterology Unit, UFR/SDS, CUP, Ouahigouya, Burkina Faso \\ Email: *sosthenesomda@gmail.com, ksosthene_somda@yahoo.fr
}

How to cite this paper: Somda, K.S., Sermé, A.K., Coulibaly, A., Zoungrana, S.L., Compaoré, I., Kouamou, S., Ouattara, D., Sombié, R. and Bougouma, A. (2016) Treatment of HBeAg-Negative Chronic Hepatitis B Patients with Nucleos(t)ide Analogues in Burkina Faso. Open Journal of Gastroenterology, 6, 387-396.

http://dx.doi.org/10.4236/ojgas.2016.612041

Received: November 7, 2016

Accepted: December 9, 2016

Published: December 12, 2016

Copyright $\odot 2016$ by authors and Scientific Research Publishing Inc. This work is licensed under the Creative Commons Attribution International License (CC BY 4.0).

http://creativecommons.org/licenses/by/4.0/

\section{Abstract}

The treatment of chronic hepatitis $\mathrm{B}(\mathrm{CHB})$ has increased significantly in recent years. In patients affected by $\mathrm{HBeAg}$-negative $\mathrm{CHB}$, it is necessary to distinguish the inactive carriers (low viral DNA $<2000 \mathrm{IU} / \mathrm{mL}$, normal ALT, histological lesions absent or minimal) who does not need treatment, and patients suffering from active CHB (DNA > $2000 \mathrm{IU} / \mathrm{ml}$, high transaminases or fluctuating, significant fibrosis and/or necro-inflammatory activity $>1$ ) who must be treated. The main purpose of treatment is to obtain a long-lasting viral suppression to improve the histological lesions and reduce the risk of evolution towards cirrhosis, liver failure and hepatocellular carcinoma (HCC). It about an indefinite treatment (unless HBsAg seroclearance) expensive and often inaccessible for the majority of our patients. Our study aimed to report the results of four years follow-up of HBeAg-negative patients treated by Nucleos(t)ide analogues (NAs) in Ouagadougou (Burkina Faso). It was a clinical observational study with 133 patients including $95 \mathrm{men}$; the average age was 41.2 years, completing the criteria of treatment. One hundred and twelve patients were treated by tenofovir (TDF), fourteen by lamivudine and seven co-infected HIV/HBV patients by Atripla ${ }^{\circledR}$ (combination TDF, Emtricitabine and Efavirenz). Virological and biochemical responses were respectively $100 \%$ and $94 \%$ after 4 years. The rate of HBsAg seroclearance was $1.5 \%$. Twelve of fourteen patients $(85.7 \%)$ had lamivudine resistance and no cases of resistance in the TDF and Atripla ${ }^{\circledR}$ groups. One co-infected patient developed HCC during treatment. Among patients treated by TDF, two cases of hypophosphatemia were noticed and no case of kidney failure. The treatment of $\mathrm{CHB}$ is 
certainly progressing; updated guidelines (EASL, AASLD) exist but should be adapted to the African context.

\section{Keywords}

Chronic Hepatitis B, HBeAg-Negative, Nucleos(t)ide Analogues, Tenofovir, Lamivudine, Burkina Faso

\section{Introduction}

With more than 350 million chronic carriers worldwide, about $5 \%$ of the world population, the hepatitis $B$ virus (HBV) infection is a major problem of public health [1] [2] [3]. Among these chronic carriers the morbidity and the mortality will be bound in $20 \%$ to $25 \%$ of the cases in a hepatic complication mainly the cirrhosis with the risk of fatal complications such as hepatic failure or hepatocellular carcinoma (HCC).

These complications are responsible of more than one million deaths yearly worldwide [4]. The primitive cancer of the liver is one of the most frequent cancers in the world and the HBV is responsible for $75 \%$ of these cancers [3].

Sub-Saharan Africa and South Asia are high endemic areas where most infections occur during the perinatal period and the early childhood, what favorites the passage in the chronicity [5] [6].

Burkina Faso is one of the highly endemic areas with prevalence about $15 \%$ [7]. The treatment of $\mathrm{CHB}$ clearly progressed during the last years. In HBeAgnegative $\mathrm{CHB}$ patients, it is necessary to distinguish the inactive carriers (low viral DNA $<2000 \mathrm{IU} / \mathrm{mL}$, normal ALT, absent or minimal histological lesions) that does not need treatment; and patients with chronic active hepatitis B (DNA > $2000 \mathrm{IU} / \mathrm{ml}$, high transaminases or fluctuating, significant fibrosis and/ or necroinflammatory activity $>1$ ) who must be treated. The main goal of treatment is to get a dural viral suppression to improve the histological lesions and reduce the risk of progression to cirrhosis, liver failure and HCC.

Two different treatment strategies are currently available: a short-term treatment with pegylated interferon alpha (PEG-IFN) or long-term therapy with nucleot(s)ide analogues (NAs). In order to assess the effectiveness of treatment and monitoring of patients, different markers (virological, biochemical, serological and histological) are used. Virological response resulted in the reduction or the non-detectability of viral DNA; this is a direct proof of the antiviral efficacy. The ALT normalization and improvement in liver histology are also therapeutic efficacy criteria. The ultimate goal of treatment is HBsAg seroclearance associated with healing of $\mathrm{CHB}$, which is rarely obtained [3] [8].

Vigano et al. [8] reported in $\mathrm{CHB}$ HBeAg-negative patients that long-term administration of NAs such as entecavir (ETV) or Tenofovir (TDF) suppresses 
HBV replication in $>95 \%$ of patients after 5 years of treatment with high rates of biochemical normalization, regression of fibrosis and cirrhosis. Papatheodoridis [9] also reported that ETV and TDF, have minimal or no risk of long-term resistance and a virological response is achieved in almost $100 \%$ of adherent HBeAg-negative patients. The main limitation of NAs is the need for long-term, perhaps indefinite, treatment and the main advantage of PEG-IFN is the finite duration (48 weeks). Nowadays new therapeutic options are needed to increase the rates of HBsAg loss. For this reason new trials based upon a combination of PEG-IFN and third generation NAs in both naïve and NA-responder HBeAgnegative patients are ongoing [8].

Our study aimed to report the results of four years follow-up of HBeAgnegative naive patients treated by NAs in Ouagadougou (Burkina Faso).

\section{Patients and Methods}

It was a clinical study made on prospective observational period from July 2011 to June 2015 in the Gastroenterology unit of Yalgado Ouédraogo teaching Hospital and Saint Camille Hospital Ouagadougou (HOSCO). We recruited consecutively a cohort of $\mathrm{HBeAg-negative} \mathrm{CHB}$ patients who completing the criteria of treatment.

\subsection{Patients}

After counseling the patient about transmission, prevention and treatment of hepatitis B, a medical record was made. Demographic, clinical (physical examination, personal and family histories) and laboratory from an initial balance (abdominal ultrasound, AST/ALT, HBeAg/anti-HBe, viral DNA, liver fibrosis evaluation) were collected from each patient.

The study population consisted of patients treated for CHB. The patients over 15 years old HBeAg-negative naive (never previously treated for CHB by NAs or pegylated-interferon) with the initial assessment in the criteria for treatment, were included. These criteria were:

- DNA $\geq 2000 \mathrm{IU} / \mathrm{ml}$ and significant fibrosis (>F1) and/or necroinflammatory activity score of at least moderate (A2) on the METAVIR score

- ALT > in twice the upper limit of normal (ULN) on several consecutive tests with DNA $\geq 2000 \mathrm{IU} / \mathrm{ml}$ independently of the fibrosis. The ULN being $30 \mathrm{IU} / \mathrm{ml}$ for the men and $19 \mathrm{IU} / \mathrm{ml}$ for the women

- Cirrhosis with detectable DNA regardless of ALT level

- Age > 40 years and family histories of HCC were additional arguments in favor of treatment.

All patients who could not provide financially for their treatment were excluded.

\subsection{Methods}

The HBsAg was checked once yearly, HBV DNA every 4 - 6 months until viral 
suppression and every 6 months or once yearly. Transaminases were monitored every 3 months at the beginning of treatment and biannual after the biochemical response. HBsAg detection techniques were Determine ${ }^{\mathrm{TM}}$ (Abbott) and Elisa $\left(\right.$ Vidas $\left.^{\circledR}\right)$. The quantification of HBV DNA was performed by real-time PCR according to Roche technique: Cobas TaqMan ${ }^{\circledR}$ and Ampliprep ${ }^{\circledR}$, sensitivity threshold of 12 IU.

Search of co-infection by HIV (human immunodeficiency virus) and HCV (hepatitis $\mathrm{C}$ virus) was routinely done before treatment. In case of viral suppression without ALT normalization, search of hepatitis delta virus (HDV) was requested. The HDV is not systematically sought in early treatment because of the high cost (about $€ 50$ ), and it is also rare in our context.

An initial abdominal ultrasound was performed, when it was normal, it was repeated annually. In patients receiving TDF, creatinine and serum phosphorus were performed at baseline, one month and then quarterly. For cirrhosis and HCC, diagnostic criteria were clinical (liver characters), biological, endoscopic, radiological and/or the Fibromètre ${ }^{\circledR}$ (non invasive method for assessing fibrosis). All patients were classified at least A2 and/or F2 on METAVIR score and/or had family histories of HCC (father or mother or brother died of CHC) with ALT twice higher than the upper limit of normal (ULN) on multiple controls. The response to treatment was estimated by the following elements:

- Virological response is undetectability of DNA load under treatment (DNA $<12 \mathrm{IU} / \mathrm{ml})$.

- Biochemical response is defined by ALT normalization (ALT < $30 \mathrm{IU} / \mathrm{ml}$ )

- HBsAg seroclearance is negativation of the HBs antigen (AgHBs) and the appearance of antibody anti-HBs (Anti-HBs) which means healing.

- Histological response is the regression of the degree of fibrosis or necroinflammatory activity under treatment effect.

The cost of management (additional tests, drugs) was on charge of the patient who was called if necessary for follow-up.

The data collected were analyzed using microcomputer with the aid of software Epi info 3.5.4 (French version).

\section{Results}

Demographic characteristics of the patients were presented in Table 1. One hundred thirty three (133) patients were included with 95 men $(71.43 \%)$ with a sex ratio of 2.5. The average age was 41.2 years (extreme ages were 20 and 73 years). $64 \%$ represented the age group over than 35 years old. The employees (public and private) represented $63.16 \%$. The circumstances of HBsAg discovery were during a check-up in $45 \%$ of cases, a blood donation in $25 \%$, a record in cirrhosis in $5.25 \%$ and an asthenia in $3.75 \%$. A risk factor was found in $20 \%$ of cases; such as previous surgery and dental treatment respectively in $10 \%$ and $7.5 \%$ and others (female genital mutilation, scarification, blood transfusion and 
Table 1. Basics characteristics of study population.

\begin{tabular}{|c|c|c|c|}
\hline Designation & Number $(N=133)$ & Percentage & Observation/cost \\
\hline \multicolumn{4}{|l|}{ Sex } \\
\hline Men & 95 & $71.43 \%$ & \\
\hline women & 38 & $28.6 \%$ & \\
\hline \multicolumn{3}{|l|}{ ALT before treatment } & $\$ 8$ US \\
\hline$\geq 2$ ULN & 60 & $45.11 \%$ & \\
\hline ]1 - 2ULN[ & 36 & $27.06 \%$ & \\
\hline normal ALT & 37 & $27.8 \%$ & \\
\hline \multicolumn{3}{|c|}{ DNAB before treatment $(\mathrm{N}=133)$} & $\$ 100$ US \\
\hline$>8 \log$ & 8 & $6.01 \%$ & \\
\hline$[6-8 \log [$ & 25 & $18.79 \%$ & All had DNA $\geq 2000 \mathrm{UI} / \mathrm{ml}$ \\
\hline$[3-6 \log [$ & 100 & $75.18 \%$ & \\
\hline \multicolumn{3}{|c|}{ Fibrosis before treatment $(\mathrm{N}=44)$} & $\$ 130$ US \\
\hline$\geq$ F2 & $26 / 44$ & $59.09 \%$ & \\
\hline \multicolumn{4}{|c|}{ Activity before treatment } \\
\hline$\geq \mathrm{A} 2$ & $13 / 44$ & $29.54 \%$ & \\
\hline \multicolumn{4}{|c|}{ Molecules used $(\mathrm{N}=133)$} \\
\hline Lamivudine & 14 & $10.52 \%$ & 12 patients had resistance after 4 years \\
\hline Ténofovir & 112 & $84.21 \%$ & \$6 US/month via HIV program \\
\hline Atripla ${ }^{\circledR}$ & 7 & $5.26 \%$ & Co-infected HIV/HBV \\
\hline \multicolumn{3}{|c|}{ Liver ultrasound $(\mathrm{N}=133)$} & $\$ 20$ US \\
\hline Normal & 98 & $73.68 \%$ & \\
\hline Liver steatosis & 11 & $8.27 \%$ & \\
\hline Cirrhosis & 19 & $14.28 \%$ & \\
\hline micronodular liver & 4 & $3 \%$ & \\
\hline $\mathrm{HCC}$ & 1 & $0.7 \%$ & Co-infected HIV/VHB \\
\hline \multicolumn{3}{|l|}{ Fibroscan $(\mathrm{N}=10)$} & Acsess in EUROPE \\
\hline$<8 \mathrm{Kpa}$ & 8 & $80 \%$ & \\
\hline $8.8 \mathrm{Kpa}$ & 1 & $10 \%$ & \\
\hline $26.3 \mathrm{Kpa}$ & 1 & $10 \%$ & \\
\hline
\end{tabular}

ULN: Upper limit of Normal. HCC: Hepatocellular carcinoma. Kpa: Kilopascal

family histories of HCC) in 2.5\%. Seven patients were co-infected HIV/HBV. 96 patients (72.18\%) had high ALT before treatment. 37 patients (28.8\%) had normal ALT before treatment with significant fibrosis $(\geq \mathrm{F} 2)$ or family histories of HCC. The average value of DNA was $10,989,541 \mathrm{IU} / \mathrm{mL}$ before treatment. Nineteen patients had cirrhosis according to the liver ultrasound.

\section{Responses to treatment}

One hundred twelve patients were treated by TDF, 14 by lamivudine and 7 co-infected HIV/HBV were treated by Atripla ${ }^{\circledR}$ (Combination TDF+ emtricita- 
bine + effavirenz).

Virological response is represented by Figure 1 and biochemical response (normalization of ALT) by Figure 2. The virological response increased gradually from the first year (64\%) to the fourth year of treatment (100\%). The biochemical response had also gradually increased from $71 \%$ to $94 \%$ in fourth year (Figure 2). In the remaining 6\% abnormal ALT patients the search of hepatitis delta virus was done and was negative.

Two patients among 133 made an HBsAg seroclearance (1.5\%).

Among 44 patients who estimated the fibrosis before treatment only 20 made a control during the treatment, for 12 of them the necroinflammatory activity score decreased and for 7 the fibrosis score decreased by one point.

\section{Resistance to treatment}

Twelve among the 14 patients on lamivudine (85.7\%) had made resistance after four years of treatment for who TDF was added until virosuppression and then monotherapy with tenofovir. No case of resistance was noted in patients on

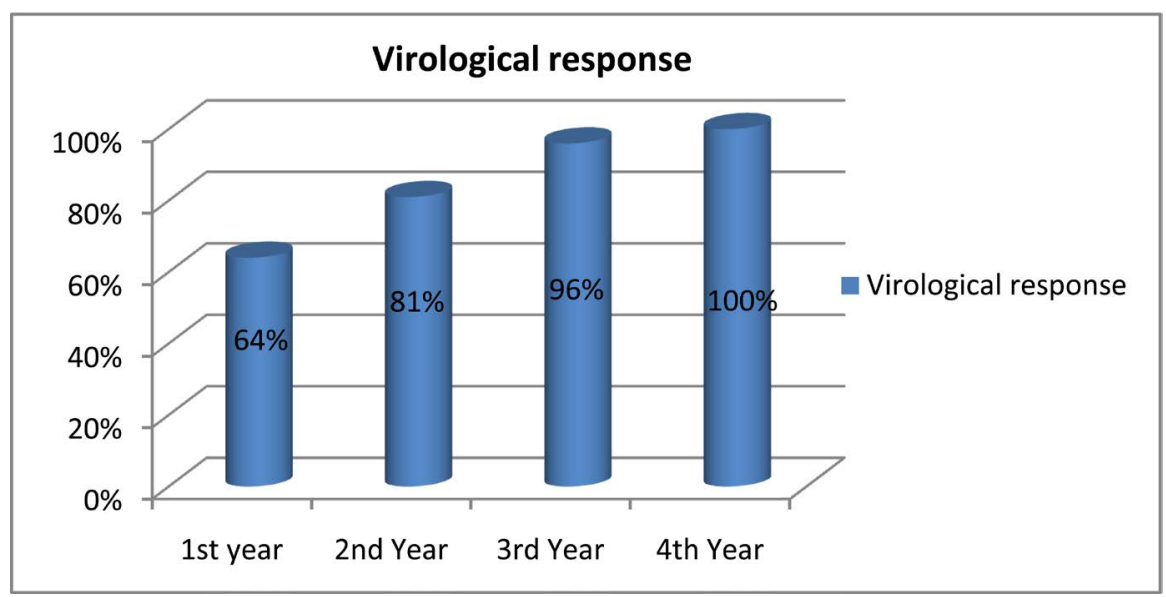

Figure 1. Virological response.

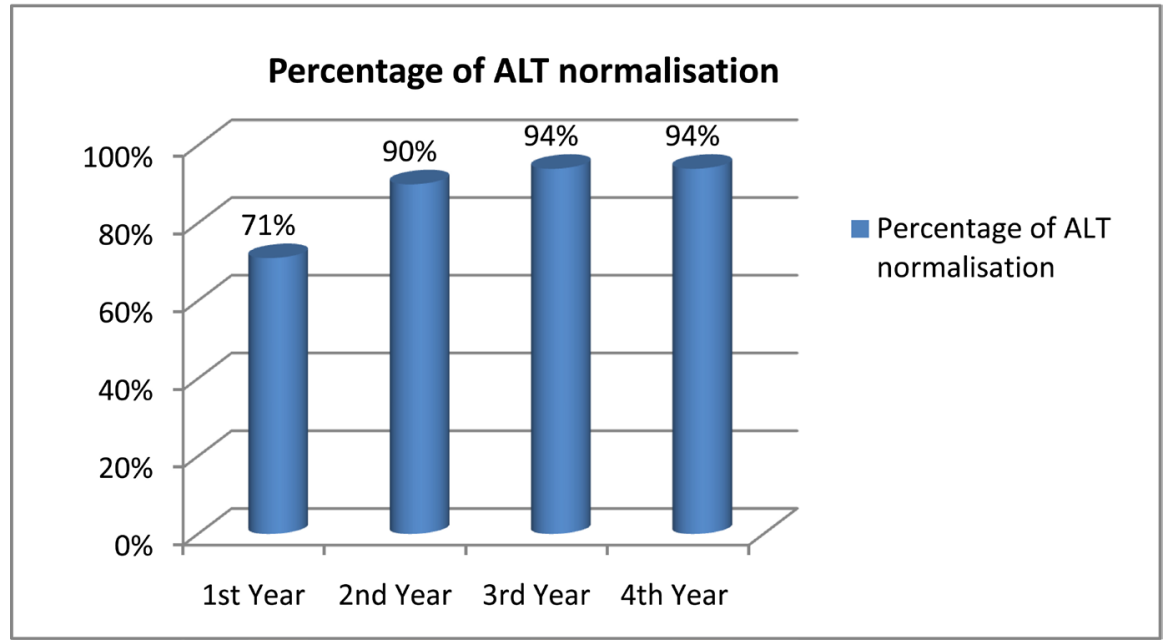

Figure 2. Biochemical response. 
TDF or Atripla ${ }^{\circledR}$.

\section{Treatment monitoring}

In patients receiving TDF, two presented moderate hypophosphatemia which spontaneously corrected. No case of kidney failure was noticed. One co-infected patient $\mathrm{HBV} / \mathrm{HIV}$ with cirrhosis has developed a HCC with a size inferior to 4 centimeters and was treated by hepatectomy. For this patient during two years follow-up we do not notice any recidivism.

\section{Discussion}

\section{Study limitations}

In this study, the cost of medical exams and treatment was fully supported by patients. In developing countries most of people live below poverty, the treatment of diseases especially chronic diseases such as hepatitis B is a challenge. Most of the patients do not have medical insurance. This situation has been a selection bias and explains the small number of patients included.

In spite of these limitations we believe that we have achieved our objective which was to report the results of four years follow-up of naive-HBeAg-negative CHB patients treated by NAs in Ouagadougou.

Indications to treatment

The main indication of treatment is viral replication (detectable DNA) with significant fibrosis score (at least F2) or a necroinflammatory activity score in at least A2 [10] [11]. In our study all patients had a higher viral replication superior or equal to $2000 \mathrm{IU} / \mathrm{ml}$ with an average of $10,989,541 \mathrm{IU} / \mathrm{mL}$ or $7.04 \log (2.7$ 8.04). 44 patients realized the Fibromètre ${ }^{\circledR}$ of which 26 had significant fibrosis $(\geq$ F2) and 13 necroinflammatory moderate activity. The other patients were treated on basis of high ALT ( $>2 \mathrm{ULN}$ ) on successive tests and family histories of HCC. In HBeAg-negative patients with DNA superior than $2000 \mathrm{UI} / \mathrm{ml}$ and ALT higher twice than the ULN, treatment is indicated even without evaluation of fibrosis, because it will bring only useful additional information but will not modify the decision of putting under treatment [1] [10] [11].

Sub-Saharan Africa is a high prevalence area for HBV infection, contamination occurs in the perinatal period and infancy. The chronicity is greater and the risk of developing cirrhosis and/or HCC occurs at an early stage [5]. It is therefore necessary to refine the recommendations of EASL and AASLD to adapt them to the African epidemiological context.

\section{Virological response}

After 4 years of treatment $100 \%$ (Figure 1) of patients had a virological response. The main purpose of treatment is to get a dural viral suppression to improve the histological lesions and reduce the risk of progression to cirrhosis, liver failure and HCC. In fact several studies have shown that a suppression of viral replication in $60 \%-70 \%$ of patients after one year of treatment with lamivudine and $79 \%$ in patients treated with tenofovir [3] [8]. 


\section{Biochemical response}

The ALT normalization was observed in $94 \%$ of patients (Figure 2). A virus-removal is associated with normalization of transaminase levels, improved histological lesions and a decreased risk of progression to cirrhosis and HCC [1] [12]. A persistent high ALT on treatment after viral suppression may be due to co-infection with hepatitis delta virus or concomitant use of drugs with enzymeinducing activity. In our context many patients take herbal medicines or traditional medicines (self-medication) the same time as analogous to treat hepatitis. These alternative treatments may partly explain the persistence of high liver enzymes levels.

\section{HbsAg seroclearance}

The ultimate purpose of antiviral therapy is to get this clearance, which demonstrates the healing but rarely achieved in particular with NAs [9] [13]. The rate of HbsAg seroclearance is better with pegylated-interferon therapies. Two of our patients (1.5\%) were cured under treatment.

\section{Resistance management treatment}

Twelve patients on fourteen (85.7\%) treated with lamivudine were resistant during treatment. In these patients TDF was added to lamivudine until viral suppression, then by monotherapy with TDF. TDF was used instead of lamivudine in the two remaining lamuvudine patients. No cases of resistance are described in patients on tenofovir [1].

\section{Co-infection HBV/HIV}

Due to a similar mode of transmission of HIV and HBV, the HBV co-infection is common in the population of HIV positive individuals. If HBV does not appear to influence the natural history of HIV, conversely, HIV alters the natural history of HBV. HIV causes, compared to HBV mono-infected subjects, lower values of ALT, increased viral replication $B$, decreased rates of spontaneous HbeAg and HbsAg seroclearance, faster liver fibrosis progression and increased risk of hepatic decompensation, cirrhosis, HCC and hepatic mortality [14] [15] [16]. A co-infected patient HIV/HBV with liver cirrhosis in our study developed HCC under treatment and was operated by regulated hepatectomy. For this patient during two years follow-up we do not notice any recidivism.

\section{Side effects}

Nucleos(t)ide analogues (NAs) have a good profile of tolerance compared with the pegylated-interferon [17]. It is important to insist on the adherence which remains the main factor of efficiency of treatment with NAs [18]. Cases of kidney failure and hypophosphatemia failure have been reported in patients taking TDF [19] [20]. In our study two patients under TDF presented moderate hypophosphatemia which spontaneously corrected.

\section{Conclusion}

Treatment of $\mathrm{CHB}$ in Africa is a challenge in particular for HBeAg-negative 
patients because of its indefinite duration and thus of its long-term high cost. The guidelines regarding treatment of hepatitis B of the EASL (European Association for the Study of the Liver) in 2012 and the AASLD (American Association for Study of Liver Disease) in 2015 are difficult to apply in countries where more than half population lives below the poverty line and thus without health care insurance. Africa is a high prevalence area for the hepatitis $B$, so it is necessary that the African practitioners think to adapt these recommendations to their context.

\section{References}

[1] Choi, M.S. and Yoo, B.C. (2010) Management of Chronic Hepatitis B with Nucleoside or Nucleotide Analogues: A Review of Current Guidelines. Gut and Liver, 4, 15-24. https://doi.org/10.5009/gnl.2010.4.1.15

[2] Pradat, P. (2006) Épidémiologie et santé publique: Un problème planétaire. In: Trépo, C., Merle, P. and Zoulim, F., Eds., Hépatites virales $B$ et $C$, John Libbey, Paris, 11-16.

[3] Asselah, T., Lada, O., Boyer, N., et al. (2008) Traitement de l'hépatite chronique B. Gastroentérologie Clinique et Biologique, 32, 749-68. https://doi.org/10.1016/j.gcb.2008.07.001

[4] Vallet-Pichard, A. and Pol, S. (2014) Hepatitis B Virus Treatment beyond the Guidelines: Special Populations and Consideration of Treatment Withdrawal. Therapeutic Advances in Gastroenterology, 7, 148-155. https://doi.org/10.1177/1756283X14524614

[5] Sombié, R., Bougouma, A., Diallo, O., Bonkoungou, G., et al. (2010) Chronic Hepatitis B: Epidemiological, Diagnostic, Therapeutic and Evolution at the University Hospital Yalgado Ouédraogo of Ouagadougou. Journal Africain d'Hépato-Gastroentérologie, 4, 3-10.

[6] Doerig, C., Antonino, A., Pache, I. and Moradpour, D. (2010) Prise en charge de l'hépatite B chronique: Un défi en évolution constante. Rev Med Suisse, 6, 168-173.

[7] Tao, I., Compaoré, T.R., Diarra, B., et al. (2014) Seroepidemiology of Hepatitis B and $\mathrm{C}$ Viruses in the General Population of Burkina Faso. Hepatitis Research and Treatment, 2014, Article ID: 781843.

[8] Viganò, M., Mangia, G. and Lampertico, P. (2014) HBeAg-Negative Chronic Hepatitis B: Why Do I Treat My Patients with Nucleos(t)ide Analogues? Liver International, 34, 120-126. https://doi.org/10.1111/liv.12401

[9] European Association for the Study of the Liver (2012) EASL Clinical Practice Guidelines: Management of Chronic Hepatitis B Virus Infection. Journal of Hepatology, 57, 167-185. https://doi.org/10.1016/j.jhep.2012.02.010

[10] Terrault, N.A., Bzowej, N.H., Chang, K.M., Hwang, J.P., Jonas, M.M. and Murad, M.H. (2016) AASLD Guidelines for Treatment of Chronic Hepatitis B. Hepatology, 63, 261-283. https://doi.org/10.1002/hep.28156

[11] Gournay, J. (2016) Hépatite chronique B: prise en charge, surveillance et traitement. FMC-HGE Post'U. 187-190. Paris/ 17 au 20 mars.

[12] Papatheodoridis, G.V. (2013) Why Do I Treat HBeAg-Negative Chronic Hepatitis B Patients with Nucleos(t)ide Analogues? Liver International, 33, 151-156. https://doi.org/10.1111/liv.12054 
[13] Liu, A., Ha, N.B., Lin, B., Yip, B., Trinh, H.N., Nguyen, H.A., et al. (2013) Low Hepatitis B Envelope Antigen Seroconversion Rate in Chronic Hepatitis B Patients on Long-Term Entecavir $0.5 \mathrm{mg}$ Daily in Routine Clinical Practice. European Journal of Gastroenterology \& Hepatology, 25, 338-343. https://doi.org/10.1097/MEG.0b013e32835b3677

[14] Miailhes, P. (2006) Co-infectés VIH/VHB. In: Trépo, C., Merle, P. and Zoulim, F., Eds., Hépatites virales $B$ et $C$, John Libbey, Paris, 86-91.

[15] Fattovich, G. (2003) Natural History and Prognosis of Hepatitis B. Seminars in Liver Diseases, 23, 47-58. https://doi.org/10.1055/s-2003-37590

[16] McMahon, B.J. (2004) The Natural History of Chronic Hepatitis B Virus Infection. Seminars in Liver Diseases, 24, 17-21. https://doi.org/10.1055/s-2004-828674

[17] Papatheodoridis, G.V. (2011) Treatment of HBeAg-Negative Chronic Hepatitis B Patients with Nucleos(t)ide Analogues. Liver International, 31, 95-103. https://doi.org/10.1111/j.1478-3231.2010.02392.x

[18] Sogni, P. and Leroy, V. (2011) l'observance: Le principal facteur d'efficacité du traitement par les analogues anti-VHB. La lettre de l'Hépato-gastroentérologue, Vol $\mathrm{XIV}-\mathrm{n}^{\circ} 1$. Janvier-février.

[19] Cooper, R.D., Wiebe, N., Smith, N., Keiser, P., Naicker, S. and Tonelli, M. (2010) Systematic Review and Meta-Analysis: Renal Safety of Tenofovir Disoproxil Fumarate in HIV-Infected Patients. Clinical Infectious Diseases, 51, 496-505. https://doi.org/10.1086/655681

[20] Buti, M., Tsai, N., Petersen, J., Flisiak, R., Gurel, S., Krastev, Z., et al. (2015) SevenYear Efficacy and Safety of Treatment with Tenofovir Disoproxil Fumarate for Chronic hepatitis B Virus Infection. Digestive Diseases and Sciences, 60, 1457-1464. https://doi.org/10.1007/s10620-014-3486-7

\section{Submit or recommend next manuscript to SCIRP and we will provide best service for you:}

Accepting pre-submission inquiries through Email, Facebook, LinkedIn, Twitter, etc.

A wide selection of journals (inclusive of 9 subjects, more than 200 journals)

Providing 24-hour high-quality service

User-friendly online submission system

Fair and swift peer-review system

Efficient typesetting and proofreading procedure

Display of the result of downloads and visits, as well as the number of cited articles

Maximum dissemination of your research work

Submit your manuscript at: http://papersubmission.scirp.org/

Or contact ojgas@scirp.org 